The Lesser Whistling-Duck Dendrocygna javanica (Horsfield, 1821) is a common resident across lowland wetlands of the Indian subcontinent (Ali \& Ripley 1983; Rahmani \& Islam 2008), and OPEN ACCESS Southeast Asia. The species ranges (c) (i) across India, Nepal, Sri Lanka, Malaysia, Singapore, Indonesia, Myanmar, Thailand and Vietnam (BirdLife International 2012). It occurs on islands in the region including the Andamans, Nicobars and Maldives (Anderson \& Baldock 2001). It has been reported from the state of Assam (Choudhury 2000). It is known to prefer weedy tanks (Ali \& Ripley 1983) and nowadays often seen visiting eutrophic water bodies full of water hyacinth Eichhornia crassipes.

The study was conducted in the premises of the Vulture Conservation Breeding Centre which encompasses two hectares of land. It is located in the Rani block of Kamrup District and falls under the Jorasal Forest Reserve. The centre is surrounded by paddy Oryza sativa fields and human habitation on three sides and on one side by forest (Image 1). Due to fencing and protection, the area has good grass growth dominated by Ulu grass Imperata arundinacea. The grassland patches are utilized as breeding grounds by small mammals (e.g., Indian Hare Lepus nigricollis, Grey Mongoose Herpestes edwardsii) and by various birds (Watercock Gallicrex cinerea, Ruddy-breasted Crake Porzana fusca, Zitting Cisticola Cisticola juncidis). The reserve forest areas are continuous with the privately owned lands in Meghalaya and are occasionally visited by large mammals such as Asian Elephant Elephas maximus, Hoolock Gibbon

\section{NESTING OF LESSER WHISTLING-DUCK DENDROCYGNA JAVANICA (HORSFIELD, 1821) (AVES: ANSERIFORMES: ANATIDAE) AND BROKEN-WING DISTRACTION DISPLAY AT KAMRUP DISTRICT, ASSAM, INDIA}

\section{Sachin P. Ranade ${ }^{1}$ \& Vibhu Prakash ${ }^{2}$}

${ }^{1}$ Vulture Conservation Breeding Centre, Belguri Village, Rani, Kamrup District, Assam 781131, India ${ }^{2}$ F-23, HMT Colony, Pinjore, Panchkula District, Haryana 134101, India ${ }^{1}$ sachinranade@yahoo.com (corresponding author), ${ }^{2}$ vibhumathur@gmail.com

Hoolock hoolock, Barking Deer Muntiacus vaginalis, and Common Leopard Panthera pardus. The area is under constant anthropogenic pressure due to illegal wood cutting and stone quarries.

We studied the Lesser Whistling-Ducks for four consecutive years, 2011-2014. The duck pairs looked for nest sites in late May, and were seen mostly in the early mornings and especially in the evenings between $1600 \mathrm{hr}$ to $1830 \mathrm{hr}$. The wary pairs would land only when there was no disturbance or presence of humans around. Although described as mainly a nocturnal feeder by Ali \& Ripley (1983), the breeding birds appeared to feed during the day before returning to the nest in the evening in pairs. Once the eggs were laid, the ducks were seen one at a time. The change-over of the incubation duty was noticed mostly at noon $(n=15)$.

All nests were located on the ground, in the Ulu grass that was $0.3-1 \mathrm{~m}$ in height. The nest sites were well concealed but on careful observation, older nests could

DOI: http://dx.doi.org/10.11609/jott.2817.8.5.8824-8826 | ZooBank: urn:Isid:zoobank.org:pub:55542B4A-1594-4E7E-BC36-C19E32920B14

Editor: S. Balachandran, Bombay Natural History Society, Mumbai, India.

Date of publication: 26 May 2016 (online \& print)

Manuscript details: Ms \# 04123 | Received 28 November 2015 | Final received 21 April 2016 | Finally accepted 01 May 2016

Citation: Ranade, S.P. \& V. Prakash (2016). Nesting of Lesser Whistling-Duck Dendrocygna javanica (Horsfield, 1821) (Aves: Anseriformes: Anatidae) and broken-wing distraction display at Kamrup District, Assam, India. Journal of Threatened Taxa 8(5): 8824-8826; http://dx.doi.org/10.11609/jott.2817.8.5.8824-8826

Copyright: (C Ranade \& Prakash 2016. Creative Commons Attribution 4.0 International License. JoTT allows unrestricted use of this article in any medium, reproduction and distribution by providing adequate credit to the authors and the source of publication.

Funding: None.

Conflict of Interest: The authors declare no competing interests.

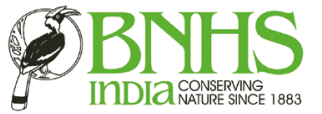

Acknowledgements: The authors would like to thank the Forest Department of Assam for their kind co-operation. We are grateful to the Bombay Natural History Society, Mumbai for constant support and encouragements. We appreciate the assistance provided by Mr. Baneshwar Das, Vulture Conservation Breeding Centre during the observations. We thank the referee for constructive comments. 


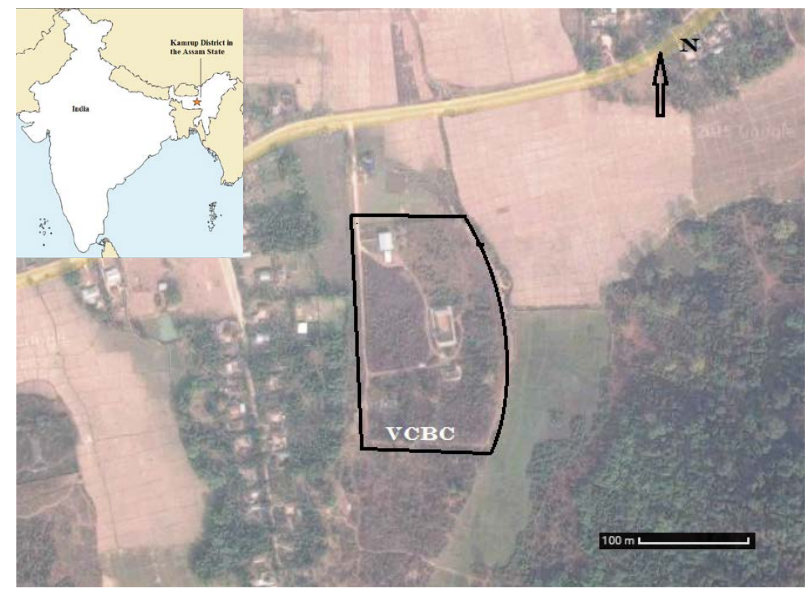

Image1. Satellite imagery of the study site in Kamrup District, Assam, India. Light colored checkered pattern is of paddy-fields with human settlements around. The hills with thin vegetation cover is on south-east of the VCBC. (Scale 100 meters)

be identified due to trampled and wilting grass strands. The sites were uniformly distributed, with an average distance of $60 \mathrm{~m}(n=6)$ between the closest nests. The nests were not lined with downy feathers (Owen \& Black 1990) but only had a padding of dried grass (Image 2).

We found six nests in 2011, four in 2012, three in 2013, and none in 2014. The average clutch size decreased through the study period with 6.8 eggs in 2011, 5.5 in 2012, and 3.6 in 2013 (Table 1). The nests were checked only once during incubation and once when they appeared abandoned by the ducks. The successful nests had clean shell remains while those raided by predators were with egg-shells and yolk remains in the grass. Out of the 13 nesting attempts, only five $(38.5 \%)$ nesting attempts were successful. The rest of the attempts failed as either no eggs were laid $(n=2 ; 15.4 \%)$ or predation by Grey Mongoose $(n=6$; $46.2 \%)$.

Out of the five successful nests we could follow only one family with parents and 10 ducklings. At the end of season, in September 2011, apparently five (50\%) ducklings survived. During the breeding season utmost care was taken to minimize disturbance to nesting birds. In spite of that, in July 2011, we noticed an incubating duck flush from the nest, cross the fence and fall to the ground. At the time we thought that the duck was startled by our presence, dashed against the fence and was injured. However, the same behavior was noticed again a couple of days later and the duck again appeared in distress, this time without collision. It became apparent that this was a display by the bird to distract our attention from the nest (Video 1 ). In both cases, the
Table 1. Year-wise breeding success in Lesser Whistling-Duck, Kamrup, Assam

\begin{tabular}{|c|c|c|c|}
\hline Year & Total nests & Successful nests & Range of clutch size \\
\hline 2011 & 6 & 3 & $2-10$ \\
\hline 2012 & 4 & 2 & $2-10$ \\
\hline 2013 & 3 & 0 & $5-6$ \\
\hline 2014 & 0 & 0 & \\
\hline
\end{tabular}

nesting bird flew about 1-2 ft above ground. It crash landed about $3 \mathrm{~m}$ from the nest as if injured, then ran in a circle for an additional $3 \mathrm{~m}$, all the time with wings fluttering on the ground, occasionally lying on the ground for a few seconds and giving distress calls. Later, the same behavior was witnessed on four more occasions in 2011 and twice in 2012. Each of these nests was successful. Our observations concur with Basu (1967) who described a similar incident where when he was about to climb a tree, a Lesser Whistling-Duck diverted his attention by engaging in a distraction display and led him away from the nest.

The distraction displays, also known as diversionary displays (Armstrong 1949) are antipredator behaviours used to attract the attention of an enemy away from an object, typically the nest or young that is being protected by a parent (Armstrong 1954; Barrow 2001). Distraction displays are sometimes classed more generically under "nest protection behaviors". The broken wing display has been recorded in lapwings and plovers-Vanellus indicus (Ali \& Ripley 1969), Vanellus crassirostris, V. armatus, V. coronatus and V. chilensis (Walters 1982), Vanellus vanellus (Cherkaoui \& Hananae 2011), Lesser Golden-Plover Pluvialis dominica dominica (Byrkjedal 1989), Alpine Accentor Prunella collaris (Barash 1975), Gnat-eater Conopophaga aurita (Leite et al. 2012), Eagle-Owl Bubo bengalensis (Ramanujam 2014), Ducks Dendrocygna eytoni and Anas chlorotis (Marchant \& Higgins 1990), Black-winged Stilt Himantopus himantopus (Wijesinghe \& Dayawansa 1998) and Sandhill Cranes Grus canadensis pratensis (Yosef 1994). The intensity of the response can be quantified to estimate the degree of disturbance to the birds by the approach of humans as was studied in the New Zealand Dotterel Charadrius obscures aquilonius (Lord et al 2001). Armstrong (1949) generalized that incubating parents appear to reach maximum display intensity around the time of hatching with progressive declines thereafter. Our observations show a similar pattern. Being a precocial species, the Lesser Whistling-Duck was observed displaying only during the hatching period. The parents guided their 


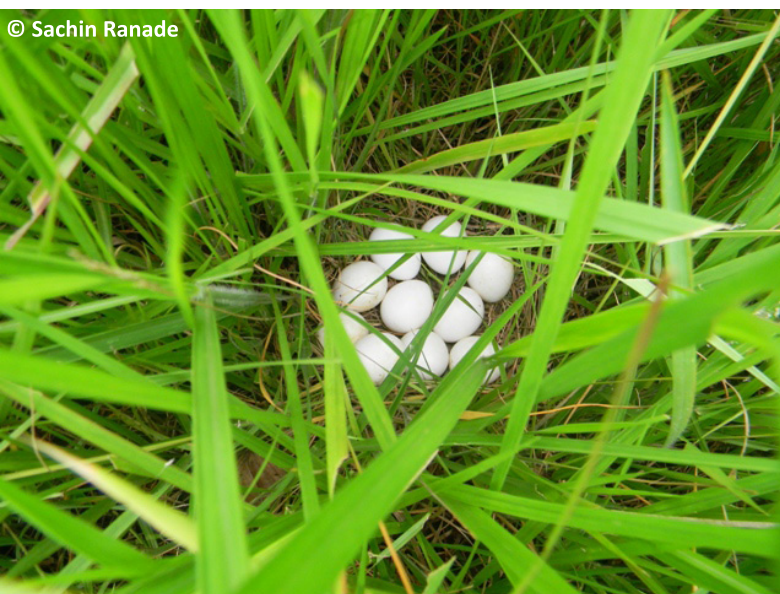

Image 2. Nest of Lesser Whistling-Duck with eggs

young to near water-body after hatching. The successful family was seen at the nearby backyard fishery pond till the end of September 2011 when five out of 10 hatchlings survived (Image 3).

The broken wing distraction display appeared to be effective in diverting the attention of the predators. Although population fluctuation is common in ducks and our data is of a short duration, it is noteworthy that the breeding attempts and breeding success declined over the four-year study period. A more extensive and focused study, with individual marking of the birds, may throw light on the status of these ducks which are for the present considered to be fairly common. It would also be of interest to elucidate the reasons leading to a decline of breeding attempts. Also of importance will be to check the status of the species on a state and countrywide basis.

\section{References}

Ali, S. \& S.D. Ripley (1983). Handbook of the birds of India and Pakistan together with those of Bangladesh, Nepal, Bhutan and Sri Lanka. Compact Edition. Bombay Natural History Society, Mumbai.

Anderson, R.C. \& M. Baldock (2001). New records of birds from the Maldives, with notes on other species. Forktail 17: 67-73

Armstrong, E.A. (1949). Diversionary display: the nature and origin of distraction display. Ibis 91: 88-97, 179-188

Armstrong, E. (1954). The ecology of distraction display. British Journal of Animal Behaviour 2(4): 121-135.; http://dx.doi.org/10.1016/ S09505601(54)800013

Barash, D.P. (1975). Evolutionary aspects of parental behavior: Distraction behavior of the Alpine Accentor. Wilson Bulletin 87(3): 367-373.

Barrows, E.M. (2001). Animal Behaviour Desk Reference. CRC Press. 2nd edition, 177pp.

Basu, B. (1967). The Whistling Teal [Dendrocygna javanica (Horsfield)] in Calcutta environs. Journal of Bombay Natural History Society 64(3): 558-559.

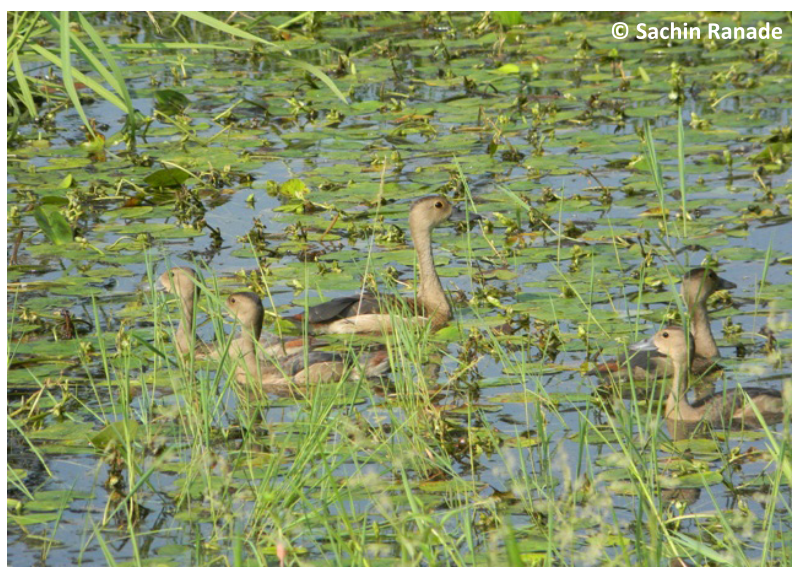

Image 3. Flock of Lesser Whistling-Ducks - an adult with grown up ducklings

BirdLife International (2012). Dendrocygna javanica. The IUCN Red List of Threatened Species 2012:e.T22679758A40105133. Downloaded on 19 May 2016; http://dx.doi.org/10.2305/IUCN.UK.2012-1.RLTS. T22679758A40105133.en

Byrkjedal, I. (1989). Nest defense behavior of Lesser Golden-Plovers. Wilson Bulletin 101(4): 579-590.

Cherkaoui, I. \& S. Hanane (2011). Status and breeding biology of Northern Lapwings Vanellus vanellus in the gharb coastal wetlands of northern Morocco. Wader Study Group Bulletin 118(1): 49-54.

Choudhury, A.U. (2000). The Birds of Assam. Gibbon Books and WWFIndia, Guwahati, 240pp.

Johnsgard, P.A. (1965). Handbook of Waterfowl Behavior: Tribe: Dendrocygnini (Whistling Ducks). University of Nebraska-Lincoln Cornell University Press, 403pp.

Leite, G.A., F.B.R. Gomes \& D.B. MacDonald (2012). Description of the nest, nestling and broken-wing behavior of Conopophaga aurita (Passeriformes: Conopophagidae). Revista Brasileira de Ornitologica 20(2): 128-131.

Lord, A., J.R. Waas, J. Innes \& M.J. Whittingham (2001). Effect of human approaches to nests of northern New Zealand dotterels. Biological Conservation 98: 233-240.

Marchant, S. \& P.J. Higgins (eds.) (1990). Handbook of Australian, New Zealand \& Antarctic Birds. Volume 1, Ratites to Ducks; Part $B$, Australian Pelican to Ducks. Melbourne, Oxford University Press, pp. 1131, 1292.

Owen, M. \& J.M. Black (1990). Waterfowl Ecology. Blackie, London, 36-65pp.

Rahmani, A.R. \& M.Z. Islam (2008). Ducks, Geese, and Swans of India: Their Status and Distribution. Indian Bird Conservation Network: Bombay Natural History Society, Royal Society for Protection of Birds and BirdLife International. Oxford University Press, 374pp.

Ramanujam, M.E. (2014). 'Broken wing display' in an unfledged Indian Eagle Owl Bubo bengalensis. Journal of Threatened Taxa 6(5): 57815783; http://dx.doi.org/10.11609/JoTT.o3791.5781-3

Walters, J.R. (1982). Parental behavior in Lapwings (Charadriidae) and its relationships with clutch sizes and mating systems. Evolution 36(5): 1030-1040.

Wijesinghe, M.R. \& P.N. Dayawansa (1998). A new antipredatory behavioural strategy in stilts suggestive of adaptive evolution. Journal of South Asian Natural History 3(2): 193-194.

Yosef, R. (1994). Sex related differences in distraction-displays by Florida Sandhill Cranes. The Condor 96: 222-224.

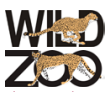

